\title{
Spin off Feasibility Study of Sharia Financing Unit: Study in Adira Finance
}

\author{
Lita Wulandari ${ }^{1}$, Hermanto Siregar $^{2}$, Hendri Tanjung $^{3}$
}

\begin{abstract}
The Financial Services Authorization (OJK) as the regulator of the finance industry has issued a policy set forth in the POJK. 28 / POJK.05 / 2014 which explains that multi-finance which has sharia portfolio as much as $50 \%$ from total business or five years from POJK is lawfully obliged to do spin-off sharia. With this policy, sharia business unit can be more focus on business development. Through this research will be analyze the feasibility of sharia financing business unit in fulfilling the aspect of separation of business unit (spin-off). Beside by observation, deep interview with Sharia Supervisory Board (DPS) and literature review, the research also use ARIMA and Double Smoothing Exponential to forecast market and financial aspect. Based on the research results sharia financing unit of Adira Finance has the ability to be spin off. But it should be noted from technology and human resources aspects.
\end{abstract}

Keyword: spin off, feasibility study, sharia-financing unit, ARIMA

\begin{abstract}
Abstrak. Otoritas Jasa Keuangan (OJK) sebagai pembuat regulasi pada industri pembiayaan telah mengeluarkan kebijakan yang tertuang pada POJK No. 28/ POJK.05/2014 yang menjelaskan bahwa multifinance yang memiliki portofolio syariah sebanyak 50\% dari total bisnis atau lima tabun dari POJK tersebut di sah kan wajib melakukan spin off syariah. Kebijakan ini akan menjadikan unit usaha syariah dapat lebih fokus terhadap pengembangan bisnis. Melalui penelitian ini akan dianalisa kelayakan unit usaha pembiayaan syariah dalam memenuhi aspek-aspek pemisahan unit bisnis (spin off). Selain observasi, wawancara dengan Dewan Pengawas Syariah (DPS) dan studi literatur, penelitian juga menggunakan metode ARIMA dan Double Smoothing Exponensial untuk prediksi pangsa pasar dan aspek keuangan. Hasil penelitian menunjukkan unit usaha pembiayaan syariah Adira Finance memiliki kemampuan untuk dilakukan spin off. Namun ada hal yang masih perlu diperhatikan yaitu: aspek teknologi dan aspek sumber daya manusia.
\end{abstract}

Kata kunci: spin off, studi kelayakan, unit usaha pembiayaan syariah, ARIMA

\section{How to Cite:}

Wulandari, L., Siregar, H., \& Tanjung, H. (2018). Spin off Feasibility Study of Sharia Financing Unit: Study in Adira Finance. Al-Iqtishad: Jurnal Ilmu Ekonomi Syariah (Journal of Islamic Economics). Vol. 10 (2): 299 - 312. doi: http://dx.doi.org/10.15408/aiq.v10i2.5781. 


\section{Introduction}

Since the enactment of Regulation of the Minister of Finance No. 43 / PMK.010 / 2012 concerning Advances on Financing of Motor Vehicles to Financing Companies that set Down Payment provisions of at least $20 \%-25 \%$ of the sale price, the acquisition of credit amount received by the financing companies was decline. One of the strategies undertaken by finance companies is by adding new business units by carrying sharia principles. Sharia financing has begun to increase significantly since the advent of the policies set about the down payment in 2012 . The number of sharia business units from 2011 to 2015 can see in Table 1.

Table 1. Number of Sharia Finance Companies

\begin{tabular}{lcccccc}
\hline \multirow{2}{*}{ Type of Company } & \multicolumn{5}{c}{ Year } \\
\cline { 2 - 6 } & $\mathbf{2 0 1 1}$ & $\mathbf{2 0 1 2}$ & $\mathbf{2 0 1 3}$ & $\mathbf{2 0 1 4}$ & $\mathbf{2 0 1 5}$ \\
\hline A sharia pure financing company & 2 & 2 & 2 & 3 & 3 \\
A finance company with a sharia business unit & 12 & 33 & 42 & 41 & 37 \\
\hline Total & 14 & 35 & 44 & 44 & 40 \\
\hline
\end{tabular}

Source: Financial Service Authority (2016)

The growth in shariah financing units presented in Table 1 is consistent with the significant growth in total assets and receivables disbursed by shariabased financing since 2012. However, total sharia financing assets are still lower than conventional financing (5,25\%-94,75\%), as well as the number of financing receivables in sharia is still smaller than conventional financing receivables $(5,57 \%$ $94,43 \%)$. Comparison of conventional financing and sharia financing shows the potential of sharia financing market to be developed.

The Financial Services Authority (OJK) as the regulator of the finance industry has issued a policy outlined in the POJK No. 28/POJK.05/2014. This regulation explains that multi finance which has sharia portfolio as much as $50 \%$ of the total business or five years from POJK is lawfully obliged to do spin-off sharia (segregation of sharia business unit). With this policy, sharia business unit can be more focus on business development.

In addition to maintaining and enlarging the market share of the Islamic financial institution non-bank (IKNB Sharia), the Financial Services Authority (OJK) has prepared the Islamic Non-Bank Financial Institution Roadmap. This roadmap is a guide for regulators, industry players and all stakeholders related to 
the policy direction and development of Islamic Non-Bank Financial Institution. Preparation of Sharia Roadmap is based on studies or research conducted by OJK on the development of Islamic Non-Bank Financial Institution. The results of these studies have resulted in several strategic issues faced by each industry sector. Regarding the compilation of the Islamic Non-Bank Financial Institution Roadmap, the strategic issues of Islamic Non-Bank Financial Institution form the basis for the preparation of action plans.

Adira Finance as one of the largest financing companies in Indonesia has owned a sharia business unit established on June 15, 2012, and under Marketing Directorate. The operational activities of sharia financing sales still join the conventional office of financing (office channeling). Total sales in each area of 2012 - 2016 are presented in Table 2.

Table 2. Total sales of Adira Finance sharia financing in the area of 2012 - 2016

\begin{tabular}{lccccc}
\hline \multirow{2}{*}{ AREA } & \multicolumn{5}{c}{ Sales Syariah by Amount } \\
\cline { 2 - 6 } & $\mathbf{2 0 1 2}$ & $\mathbf{2 0 1 3}$ & $\mathbf{2 0 1 4}$ & $\mathbf{2 0 1 5}$ & $\mathbf{2 0 1 6}$ \\
\hline JABODETABEKSER & $1,743,133$ & 94,023 & 125,337 & 539,805 & $1,537,957$ \\
SULAMPAPUA & 704,732 & 81,363 & 412,382 & 683,035 & $1,352,288$ \\
CENTRAL JAVA & 526,553 & 100,342 & 564,753 & 949,657 & $1,085,246$ \\
SUMBAGUT & 770,757 & 56,018 & 358,415 & 585,699 & 739,845 \\
SUMBAGSEL & 565,147 & 53,032 & 337,000 & 832,875 & 721,031 \\
EAST JAVA & 544,740 & 148,271 & 285,965 & 215,603 & $1,221,157$ \\
KALIMANTAN & 597,763 & 77,861 & 251,384 & 467,679 & 699,958 \\
WEST JAVA & 569,783 & 58,854 & 41,294 & 243,790 & $1,019,606$ \\
BALI-NUSRA & 85,289 & 2,561 & 1,537 & 5,189 & 13,012 \\
\hline \multicolumn{1}{c}{ TOTAL } & $\mathbf{6 , 1 0 7 , 8 9 7}$ & $\mathbf{6 7 2 , 3 2 6}$ & $\mathbf{2 , 3 7 8 , 0 6 7}$ & $\mathbf{4 , 5 2 3 , 3 3 3}$ & $\mathbf{8 , 3 9 0 , 1 0 0}$ \\
\hline
\end{tabular}

Source: Adira Multifinance (2017)

From Table 2 it can be seen that sharia financing unit of Adira Finance has experienced significant growth over the past three years, in line with the total growth of sharia financing assets in 2015 by $18.7 \%$ to $33.7 \%$ in 2016 from total business assets. Positive growth trend towards total sales of sharia financing unit of Adira Finance and refers to POJK no. 28/POJK.05/2014, Adira Finance needs to analyze the feasibility of sharia business unit if doing spin-off seen from various aspects of 
business feasibility. Therefore, the purpose of this study is to analyze the feasibility of Islamic financing business unit Adira Finance if the separation of business units (spin-off). The rest of the paper is organized in the following sequence: in the next section, the literature survey of relevant studies is provided. The research method and data, on which the analysis is conducted, are presented in Section 3. Section 4 discusses the results and implications of the paper. Lastly, section 5 concludes the paper.

\section{Literature Review}

Tabash and Dhankar (2014) argue that the main principle of Islamic financing is to prohibit the existence of riba (interest), gharar (ambiguity), speculation, and cover some of the actual information in a contract. Islamic finance theories support the economic development directly to the world economy and physical transactions including banning adverse activities and products, Islamic finance theory also promotes economic and social justice.

According to Dewati (2015) the decision to spin off not only by internal factors within the company but also requires support from external conditions. Internally, companies with potential business units have typically set targets to "release" business units that are deemed to have capabilities and competencies as stand-alone entities separate from parent companies. While from the external side, spin-off decisions must also be supported by regulations from relevant agencies as well as information regarding market opportunities that will be extracted after the business unit is separated from the parent company.

Stamboel (2012) found that three things are most often encountered during the spin-off process that is: First, spin-off plan and brief information of spin-off plan; Second, employee movement; and Third, incompatibility between regulation of Ministry of Justice and regulation of Bank Indonesia. In this study, it can also be concluded that the business environment in Indonesia has been more than ready to conduct spin-off transactions since the support of the State is still sufficient. This condition should be balanced with a single set of laws and regulations conducive to the implementation of the process, Achieve legal certainty for all parties involved in spin-off transactions.

Stempin (2016) mentioned based on the financial statements before the spinoff predicted changes in income to be obtained at $54.6 \%$ while using the Pro Forma financial statements predicted changes in revenues to be obtained by $90 \%$. Chu et al. (2010) obtained two things namely: first, spin off company performance will tend to increase if the operational activities connected with the parent company 
and CEO involvement in the parent company in providing support to utilize the resources of the parent company. Second, the spin-off company has a better performance in the early stage after leaving the parent company with the technology that has been researched and developed by the parent company.

Sasongko and Zulfikar (2016) indicate that the models of Islamic banking service policies can explain the characteristics of the spin-off and office channeling. The study found evidence of which is the spin-off model more profitable than office channeling. The level of efficiency of the spin-off model higher than the office channeling model, the spin-off model lower risk (more solvent) than office channeling model, and there are no differences in the level of liquidity and the quality of assets between the spin-off model and the office channeling model.

Research conducted by Fariani et al. (2013) found that two strategies must be done by Islamic Business Unit of Bank of BTN after the spin-off is to synergize with the parent company (Bank of BTN) and build a strong corporate culture. Research conducted by Veld and Veld-Merkoulova (2004) shows the average CAAR (cumulative average abnormal return) of all countries increased significantly at the level of $1 \%$ that is equal to $2.62 \%$ at the time of $\mathrm{H}-1 \mathrm{sd} \mathrm{H}+1$ of the announcement of the spin-off. Long-term return measurements were performed by regression method with a period of 1 and two years after the spin-off. The results show that returns are more positively related to increased industry focus, but there is no apparent link between more returns and asymmetric information. Increased rate of return occurs in spin-off companies, but in the long run, the increase is not significant.

Siswantoro (2014) in his research on eight sharia banks that have spin-off said the addition of capital in sharia banks after separated from the parent company could accelerate the growth of Islamic banks. But effective management must support it. Further Siswantoro (2014) states to be effective, capital injections should be done quickly as soon as the spin-off is done. However, sharia banks can use other sources of capital such as Sukuk and bond issuance, initial public offering (IPO) and direct investment. So far, the issuance of bonds is done to obtain capital. Al Arif (2014) conclude that there is a difference in deposit funds between pre and post spin-off activities in Islamic banks.

Al Arif (2015) in his research stated that spin-off policy does not have an impact on financing growth in Islamic bank resulted from the spin-off. This result caused the operational cost of Islamic bank resulted from spin-off is higher than operational income, especially in an earlier period of spin off the operational efficiency values (BOPO) is very high. Therefore, the Islamic bank resulted from spin-off will be more careful in order not to add finance portfolio operating expenses. Supported by Hamid (2015) showed that the dummy variable of the spin-off, NPF 
and BOPO give a significant influence on the profitability ratio (measured by ROA) of Indonesian Islamic Banking Industry.

\section{Method}

A business feasibility study was conducted to find out whether or not a business candidate is feasible (Kasmir and Jakfar, 2013). Aspects to be observed in this business feasibility study are socioeconomic aspects, legal aspects, technology aspects, aspects of human resources, market, and marketing issues, and financial aspects. The research was conducted in Syariah Financing Division of Adira Finance in March-May 2017 involving Top Management of the company as an internal party and from the external party will be represented by Sharia Supervisory Board, Academician, and practitioner in Sharia financing.

Data collection method will use purposive sampling model; there are 2 data sources used are: First, primary data which is collected from depth interview with respondents. Second, secondary data which are collected from sales data of sharia financing unit of Adira Finance for 2012 - 2016, financing report of sharia financing unit from 2013 - 2016, and library studies, newspapers, business magazines, and article

Forecasting financial ratios will be performed on total assets, NPF, total sales, Account Receivable (AR) and expense to see the financial condition of sharia financing unit of Adira Finance after the spin-off. The analysis used secondary data of sharia financing unit of Adira Finance's quarterly financial report from 2013 to 2016 and the report of sharia financing sales in 2012 - 2016. The limited availability of data for forecasting method used is Auto-Regressive Integrated Moving Average (ARIMA) and Double Smoothing Exponential. The ARIMA method will be used to predict total sales over the next two years (2017-2018) by using total sales monthly report from June 2012 until December 2016. While for NPF financial ratios, total assets, expenses, and AR will use the double smoothing exponential method by using financial report quarterly from January 2013 until December 2016.

\section{Result and Discussion}

Murabahah financing dominates the financing offered by sharia financing unit of Adira Finance, which is in the financing product of two-wheeled and fourwheeled vehicles. With the support of the parent company to sharia financing services, total sales of two-wheeled and four-wheeled vehicles sharia financing unit of Adira Finance showed positive growth. Comparison of total sales of two-wheeled 
and four-wheeled motor vehicles by sharia financing unit of Adira Finance 2012 2016 can be seen in Table 3.

From Table 3 it can be seen that until 2016 as much as 75\% of sharia financing unit of Adira Finance's financing comes from two-wheel financing and $25 \%$ is obtained from four-wheel financing. In the aspect of the social economy, a sharia-financing pattern began to be increasingly used by the community even able to print significant growth. This sharia-financing proposal is caught from the total number of motor vehicle purchases using the sharia system in the United Arab Emirates (UAE). In Middle East cosmopolitan country, the number of submissions rocketed $64.79 \%$ in 2016. Despite growing significantly, the popularity of motor vehicle loans with conventional systems at UES is still high. People who earn below 20 thousand UEA per month usually choose this model. Two things mainly trigger the high demand for sharia vehicle financing, namely: first, many banks offer to finance with attractive rates with additional discounted sharia insurance; and second, a more attractive side bid.

Table 3. Comparison of Total Sales of Two-Wheelers and Four Wheels by Sharia Financing Unit of Adira Finance 2012 - 2016

\begin{tabular}{cccccc}
\hline Year & $\mathbf{2 0 1 2}$ & $\mathbf{2 0 1 3}$ & $\mathbf{2 0 1 4}$ & $\mathbf{2 0 1 5}$ & $\mathbf{2 0 1 6}$ \\
\hline Amount Car (in Mio) & $1,037,051$ & 72,128 & 299,955 & $1,073,333$ & $2,117,776$ \\
Amount Mcy (in Mio) & $5,070,846$ & 600,198 & $2,078,101$ & $3,450,001$ & $6,272,324$ \\
Total Amount (in Mio) & $6,107,897$ & 672,326 & $2,378,067$ & $4,523,333$ & $8,390,100$ \\
\% Amount Car & $17 \%$ & $11 \%$ & $13 \%$ & $24 \%$ & $25 \%$ \\
\% Amount Mcy & $83 \%$ & $89 \%$ & $87 \%$ & $76 \%$ & $75 \%$ \\
\hline
\end{tabular}

Source: Adira Multifinance (2017)

The experience presented by Oni Sahroni -in the interview- one example of a positive policy in Malaysia is that if there is a bank that opened sharia business, it is required for each branch to offer its sharia products first to customers before conventional products. The same may be done by sharia financing in Indonesia by providing incentives, both against advances, taxes and regulatory convenience. Based on data from the Central Bureau of Statistics 2016, the number of Muslim population in Indonesia is about $87.2 \%$ of the total population. Seeing the population of Muslims in Indonesia can be an opportunity to enlarge the market of Islamic finance. 
Legal aspects represented by government regulation play a significant role in the process of establishing a business. The government will act as a regulator in the financing industry by issuing various policies to regulate the parties involved in the financing industry. The implementation of sharia financing business regulated in POJK No. 31/POJK.05/2014. This regulation describes matters related to the application of sharia financing business. In addition to supporting the development of sharia financing that is healthy, manageable, stable and inclusive so as to contribute positively to the community. The government through OJK issued Roadmap IKNB 2015-2019 which will serve as guidance for OJK and sharia IKNB actors in determining the direction of development, especially for the period 2015 - 2019.

The policy that has been issued by the government through OJK is a very positive policy to encourage the financing institution that is still a unit to immediately enlarge its assets until it can spin off. With many sharia-financing institutions, the spin-off will make the image of society towards sharia financing more positive and more models of sharia financing institutions are market-friendly and also shariah compliance (interview with Oni Sahroni -Sharia Supervisory Board).

In the financing industry, the utilization of technology is used as a means of promotion, service improvement and operational cost efficiency. Sharia financing unit of Adira Finance has implemented technology in its operational activities, and the information system owned has been integrated well with the parent company. Examples of the use of technology that has been applied are payment point technology that is done in collaboration with some retail stores for ease of payment by customers. See the development of the retail industry and has an extensive network to the corners of the village to help facilitate the customer in paying installments so minimize default rate that measured by non-performing financing (NPF) due to late payment.

However, note the arrangement of system related to the filing of financing, during this system is arranged based on filing with Murabaha agreement, this adjusts to the scheme of submission that has been running in the parent company. In the implementation of the spin-off of the Islamic business unit into a business unit needs to be prepared IT system tailored to the new shariah agreement to be used in product development. The separation of sharia financing unit and conventional employees is a matter of concern in the aspect of human resources considering the limited funds and has not yet prepared its career path and competence of human resources adequate to run sharia business.

After the spin-off, a sharia-financing unit of Adira Finance will become a new sharia company and the employees in it must understand the overall financing of sharia. Training to employees needs to be done periodically, and by the intended 
level, the provision of training can be done in cooperation with the Business School and Academy department or bring in an outside vendor training who already has the competence to provide training on sharia financing.

In the market and marketing aspects of sharia financing is one of the strategies driven by the financing industry to boost sales, in addition to sharia financing being the largest contributor to the global economic slowdown in 2015. As previously stated, although sharia-financing growth is very good when compared to conventional financing, the percentage earned is still small.

Figure 1. Forecasting sales trend of sharia financing unit of Adira Finance business unit in $2017-2018$

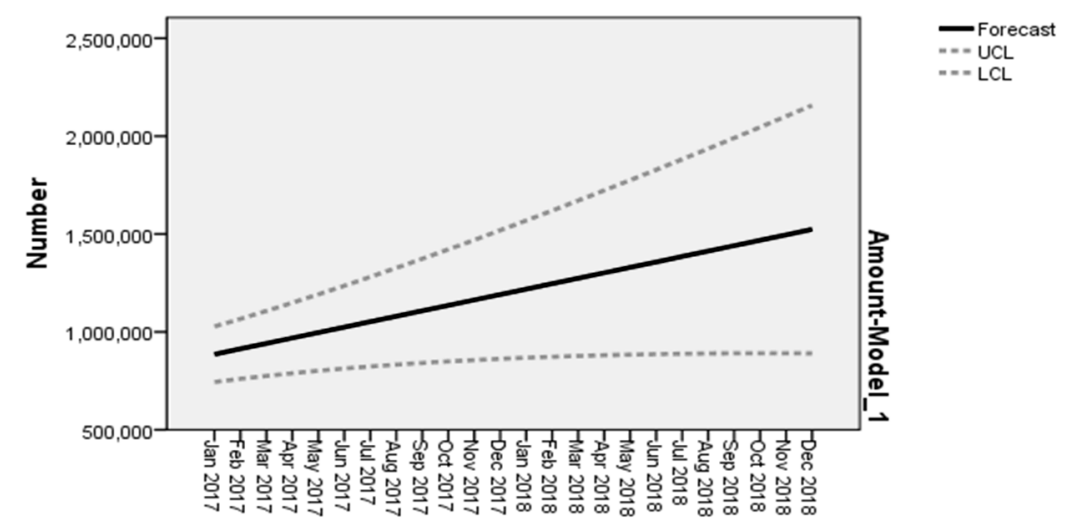

Date

According to Oni Sahroni, the low total of sharia financing with conventional can be caused by several things, among them is the level of understanding of the Indonesian people towards sharia economy is still low. The average Indonesian people are more considering the market aspect, profit, easier than the financing is sharia or not. Also, conventional financing institutions have also expanded; therefore can not necessarily be compared with Islamic finance institutions. Prediction of sales trend of sharia financing unit of Adira Finance during 2017 - 2018 with AutoRegressive Integrated Moving Average (ARIMA) method can be seen in Figure 1. From Figure 1 it can be seen that the average monthly sales increase of about $2 \%$, the average percentage of this increase is considered very good to support getting the investment from outsiders and issuance of Sukuk to get additional capital.

Broadly speaking there is three marketing activities sharia financing unit of Adira Finance namely: Firstly, product development; secondly, market development; 
thirdly, branding awarness. In product development activities, in addition to concentrating on the financing of two-wheeled and four-wheeled vehicles in accordance with the Murabahah contract, sharia-financing unit of Adira Finance began to develop new products such as financing to run the Umrah worship service that began in November 2016.

Figure 2. Results of forecasting total assets of sharia financing unit of Adira Finance in 2017-2018

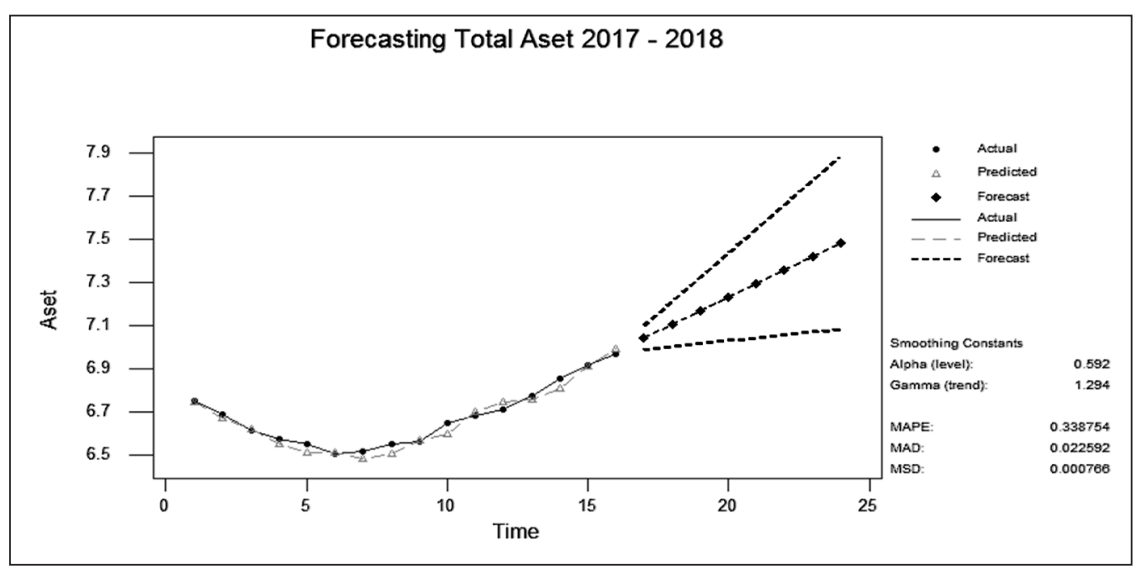

Market development activities conducted by the sharia financing unit of Adira Finance is in cooperation with Baitul Mal Wat Tamwil (BMT) who will perform its function as a marketing channel. This cooperation began in April 2017; this is done to work the market with sharia loyalist consumers better. For brand awareness activities to the external environment is done by holding a press conference at the time of launching new products, into sponsorship events-events held by partners (e.g., activities at MUI or activities organized by BMT). One of the forms of cooperation is to publish a pocketbook containing information about sharia financing. The pocketbook is provided free of charge during the event that carries the concept of sharia. Promotional materials are also sent to the branch as a form of promotional activities to the public. Promotion is done by installing billboards to big branches and being representative of area, brochure and flyer distribution, and installation of the standing banner. 
Figure 3. Results forecasting NPF sharia financing unit of Adira Finance in $2017-2018$

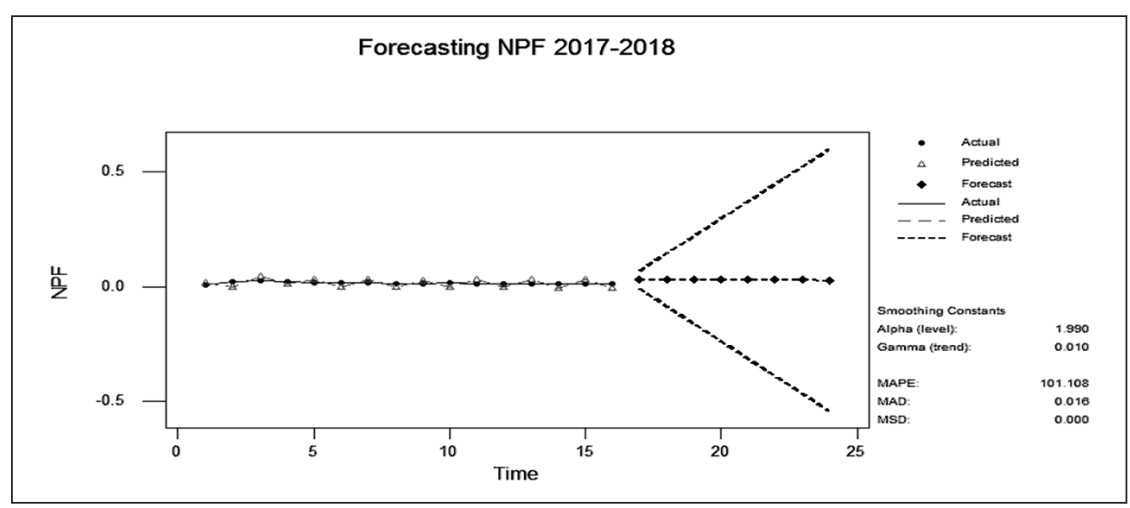

In the financial aspect analysis of sharia financing unit of Adira Finance, the financial performance forecasting performed on several financial ratios over the next two years (2017-2018). The forecasting result of several financial ratios of sharia financing unit of Adira Finance can be seen in Figure 2 to Figure 5. From Figure 2 to Figure 5 can be seen the tendency of the performance of several financial ratios have increased compared to previous times. However, it should be noted that if the prediction line is getting farther and farther with the upper and lower borders, this indicates the possibility of macro factors that might affect the performance of the financial performance.

Figure 4. Results for forecasting sharia-financing unit of Adira Finance expenses in 2017 - 2018

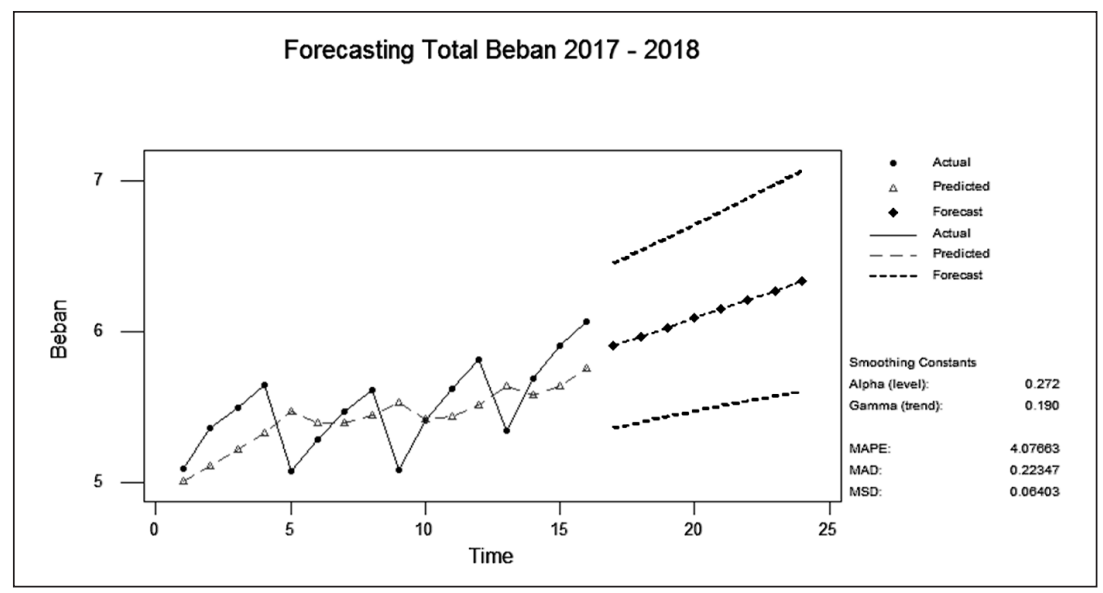


Forecasting result of expenses after spin-off show increasing trend, it inline with research that conducted by Al Arif (2015) which is show operational cost in Islamic bank resulted from spin-off is higher than operational income, especially in an earlier period of spin-off. But this forecasting result cannot prove yet Al Arif et al. research (2017) that show the operational cost show adverse effect to asset growth, because asset in financing industry is influenced not only by operational cost but also by the stability of Non-Performing Financing (NPF) and amount of Account Receivable (AR). Spin-off decision must be made with full consideration. Haribowo (2017) conclude that the Islamic bank's spin-off policy should evaluate, especially in regional development banks.

Figure 5. Results forecasting account receivable (AR) sharia financing unit of Adira Finance 2017 - 2018

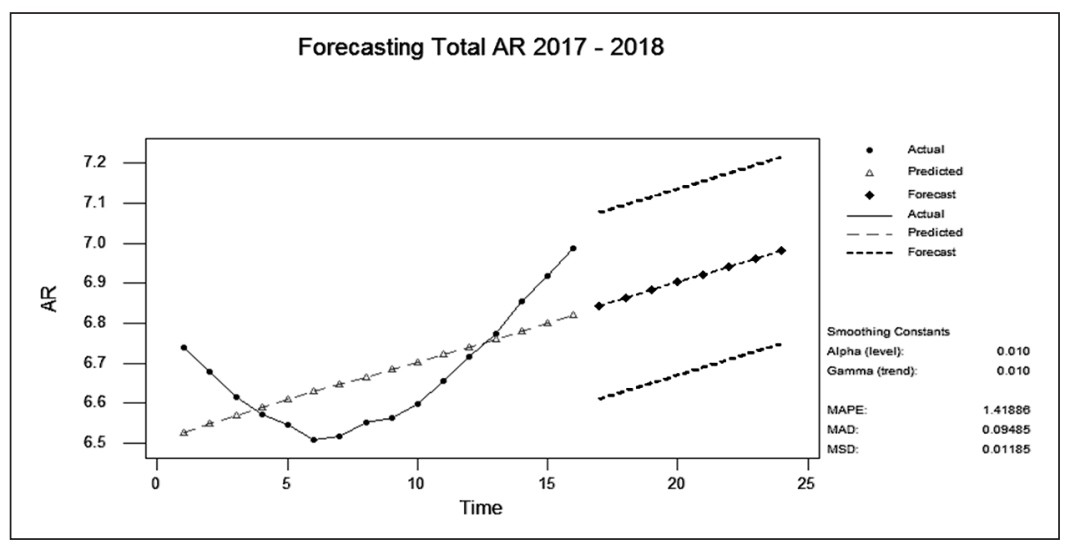

Judging from the results of business feasibility studies, a sharia-financing unit of Adira Finance can spin off. This fact is seen from the prediction of the ability of sharia financing unit of Adira Finance in developing its business as in market and marketing aspect, support from legal aspect and opportunity that can be utilized from the socio-economic aspect. But it needs to be further developed for shariafinancing unit of Adira Finance if it will be spin-off are from technology and human resources aspects.

Aspects of technology will greatly support business activities, after spin-off will be many new contracts used in product development. Therefore adjustment of IT system to sharia agreement principles needs to be developed. Technological aspects also need to be developed to improve services to consumers and decrease promotional costs. 
Aspects of human resources need to be considered in the establishment of a business. After spin-off, employees in it are required to understand the principles of sharia and the products that will be offered. It is intended to be able to promote the benefits of sharia financing products by employees to prospective customers.

\section{Conclusion}

The policy that had issued in the POJK No. 28 / POJK.05 / 2014 is a very positive policy to encourage the financing institution which is still a unit to immediately enlarge its assets until it can spin off. With many sharia-financing institutions, the spin-off will make the image of society towards sharia financing more positive and more models of sharia financing institutions are market-friendly and also shariah compliance.

Based on the results of research that has been done can be concluded that is sharia financing unit of Adira Finance can spin off. This can be seen from the feasibility indicators of market and marketing aspects, socioeconomic aspects and legal aspects. But the sharia-financing unit of Adira Finance on aspects of technology and human resources aspects should note it. In the implementation of the spin-off of the sharia business unit into a business unit needs to be prepared IT system tailored to the new sharia agreement to be used in product development. After the spin-off of sharia financing unit of Adira Finance will become a new sharia financing company, the employees in it must understand the overall financing of sharia. From the financial aspect, a sharia-financing unit of Adira Finance has an increasing trend in the asset and account receivable (AR) financial ratios, while the Non-Performing Financing (NPF) and load ratio tend to be stable.

\section{References}

Al Arif, M. N. R. (2014). Spin-off and Its Impact on The Third Party Funds of Indonesian Islamic Banking Industry. Economic Journal of Emerging Markets. Vol. 6 (1): 50-55. doi: htps://doi.org/10.20885/ejem.vol16iss1.art5.

Al Arif, M. N. R. (2015). The Effect of Spin Off Policy on Financing Growth in Indonesia Islamic Banking Industry. Journal of Al-Ulum. Vol. 15(1): 173-184.

Al Arif, M. N. R., Nachrowi, N. D., Nasution, M. E., \& Mahmud, T. M. Z. (2017). The Islamic Banking Spin off: Lesson from Indonesian Islamic Banking Experiences. JKAU: Islamic Economics. Vol. 30(2): 117-133. doi: https://doi. org/10.4197/Islec.30-2.11. 
Chu, P. Y., Teng, M. J., Lee, C.T., \& Chiu, H. (2010). Spin off Strategies and Performance: a Case Study of Taiwan`s ACER Group. Journal of Asian Business and Management. Vol. 9(1): 101-125.

Dewati, H. R. (2015). Pemilihan Metode Spin Off Unit Bisnis Syariah dengan Pendekatan Analisa Faktor: Studi Kasus PT. BNI Syariah dan PT. Bank Syariah BRI (The Decision of Spin Off Method of Islamic Business Unit by Factor Analysis Approach: Case Study on Bank of BNI Sharia and Bank of BRI Sharia). (Unpublished Thesis). Bogor: School of Business, Bogor Agricultural University.

Fariani, A., Jayaprawira, A., \&Bintoro OB. (2013). Strategy UUS BTN Post Spin Off with Scenario Planning Approach. The Indonesia Journal of Business Administration. Vol. 2(2): 169-180.

Hamid, A. (2015). The Impact of Spin-off Policy to The Probability on Indonesian Islamic Banking Industry. Al-Iqtishad: Jurnal Ilmu Ekonomi Syariah (Journal of Islamic Economics). Vol. 8(1): 117-126. doi: https://doi.org/10.15408/aiq. v8i1.1363.

Haribowo, I. (2017). The Indonesian Islamic Bank's Spin-Off: A Study in Regional Development Banks. Al-Iqtishad: Jurnal Ilmu Ekonomi Syariah (Journal of Islamic Economics). Vol. 9(1): 53-68. doi: https://doi.org/10.15408/aiq.v9i1.4308.

Kasmir, \& Jakfar. (2013). Studi Kelayakan Bisnis (Business Feasibility Study). Jakarta: Kencana Prenada Media Group

Sasongko, N., \& Zulfikar. (2016). The Model of Policy the Banking Services to Enhance Competitiveness Islamic Banking in Indonesian. South East Asian Journal of Contemporary Business, Economic and Law. Vol. 11(1): 1-8

Siswantoro, D. (2014). Analysis of Islamic Bank`s Performance and Strategy after Spin Off as Islamic Full Pledge Scheme in Indonesia. Proceeding of International Conference on Accounting Studies (ICAS). Kuala Lumpur, Malaysia

Stamboel. R. A. S. (2012). An Analysis of The Corporate Spin Off in Indonesia: Potential, Regulations and Issues. (Unpublished Thesis). Netherlands: Tilburg University.

Stempin, N. (2016). The Impact of Financial Statements for SEC Spin Off Entitites on The Market's Ability to Anticipate Future Earning. (Unpublished Dissertation). Georgia: Georgia State University

Tabash. M. I., \& Dhankar, R. S. (2014). The Relevance of Islamic Finance Principles in Economic Growth. International Journal of Emerging Research in Management \& Technology. Vol. 2: 49-54.

Veld, C., \& Veld-Merkoulova, Y. V. (2004). Do Spin Off Really Create Value? The European Case. Journal of Banking \& Finance. Vol. 28: 1111-1135. doi: https://doi.org/10.1016/S0378-4266(03)00045-1. 